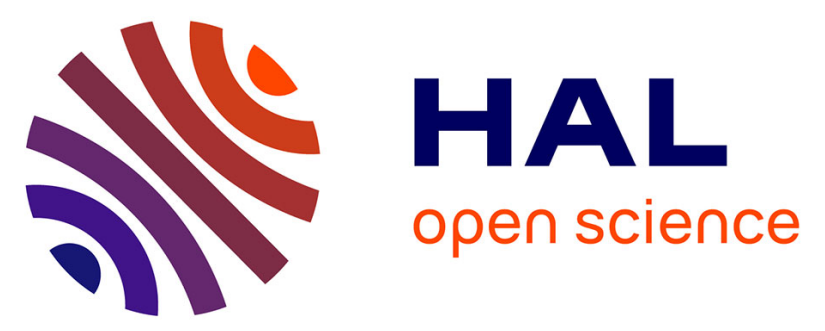

\title{
A device to study the growth of detached fruit. Depressive effect of the nutrient solution sucrose concentration on tomato fruit growth in the cell expansion phase
}

Philippe Bussieres, Nadia Bertin, Cindy E. Morris, Christian Vigne, Patrick Orlando, Catherine Glaux, Hélène Floret, Jean Bernadac, Valérie Sevenier, S.

Pfeiffer

\section{- To cite this version:}

Philippe Bussieres, Nadia Bertin, Cindy E. Morris, Christian Vigne, Patrick Orlando, et al.. A device to study the growth of detached fruit. Depressive effect of the nutrient solution sucrose concentration on tomato fruit growth in the cell expansion phase. Acta Horticulturae, 2012, 932, pp.219-222. 10.17660/ActaHortic.2012.932.31 . hal-02645290

\section{HAL Id: hal-02645290 \\ https://hal.inrae.fr/hal-02645290}

Submitted on 29 May 2020

HAL is a multi-disciplinary open access archive for the deposit and dissemination of scientific research documents, whether they are published or not. The documents may come from teaching and research institutions in France or abroad, or from public or private research centers.
L'archive ouverte pluridisciplinaire HAL, est destinée au dépôt et à la diffusion de documents scientifiques de niveau recherche, publiés ou non, émanant des établissements d'enseignement et de recherche français ou étrangers, des laboratoires publics ou privés. 


\title{
A Device to Study the Growth of Fruit. Depressive Effect of the Nutrient Solution Sucrose Concentration on Detached Tomato Fruit Growth in the Cell Expansion Phase
}

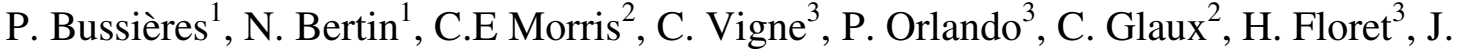 \\ Bernadac $^{3}$, V. Sévénier ${ }^{3}$ and S. Pfeiffer ${ }^{3}$ \\ ${ }^{1}$ INRA, UR 1115 Plantes et Systèmes de culture Horticoles, F-84000 Avignon, France \\ ${ }^{2}$ INRA, UR 0407 Pathologie Végétale, F-84000 Avignon, France \\ ${ }^{3}$ INRA, UR 1115 Plantes et Systèmes de culture Horticoles, F-84000 Avignon, France
}

Keywords: in vitro culture, sterile medium, sucrose

\begin{abstract}
A new semi open device, named "Casafruit", was designed to study tomato fruit growth. This device was constituted of four boxes in which tomato fruits detached from the plant were grown with their pedicel immersed in a nutrient solution. This solution was automatically replaced each day. The fruit weight could be estimated frequently. The fruits were placed in the device after an optimized disinfection treatment. As the effect of sap sucrose concentration on fruit expansion is poorly investigated, this effect was studied with Casafruit. Tomato fruits taken from plants about twenty days after anthesis were placed in the device with a nutrient solution containing $5 \%$ sucrose. After about eight days, sucrose concentration was increased to $15 \%$ in two boxes or maintained at $5 \%$ in the two other boxes. The experiment was repeated five times.

No contamination occurred. It was observed that fruit expansion rate decreased after the sucrose concentration was increased and the fruits became smaller than those grown at $5 \%$.

Although the detached fruits were smaller than fruits grown on the plant, these results suggest that a high sap sucrose concentration in the period where tomato fruit expansion depends mainly on cell expansion has a depressive effect on growth. The device "Casafruit" might be useful for diverse studies on fruit growth for instance to study the effect of sucrose in the cell multiplication phase.
\end{abstract}

\section{INTRODUCTION}

This research has two main objectives. The first was to design and build a new device, named "Casafruit", to study fruit growth in very controlled environments, especially the composition of the nutrient solution. The effect of sap sucrose concentration on fruit growth is poorly known, largely due to the difficulties to collect samples of the sap available for the fruit, consequently it was desirable to study this effect with detached fruits. In a previous experiment with young fruits placed in closed containers with nutrient solutions at different sucrose concentrations, the fruit size after about twenty days decreased with the sucrose concentration in the range of 5 to $32 \%$, thus the second aim was to use this device to study the effect of a very high sucrose concentration on the expansion of detached tomato fruits, after the cell multiplication phase which occurs about twenty days after pollination (Bertin, 2005). It was found that a very high sucrose concentration has a depressive effect on the fruit expansion. 


\section{MATERIALS AND METHODS}

In the new device, detached fruits are put in a box as shown in Fig. 1, on a flat support with holes through which the pedicels pass. The pedicels are immersed in the nutrient solution composed of Murashige and Skoog medium and of sucrose. The nutrient solution is renewed each day after a rapid treatment with a sodium hypochlorite solution in order to maintain sterility. The whole system works with solenoid valves and pumps controlled by an automatic programmable unit. The system has four independent boxes for four treatments which may be different. Each box is put on a support in such a way that the mean fruit weight can be measured after draining the solution.

This device was used to compare two treatments, using tomato fruits detached from plants after about twenty two days after anthesis. They were disinfected with alcohol for thirty seconds and then placed in the device. They were grown for about eight days with a nutrient solution of $5 \%$ sucrose. Then, in a control, the sucrose concentration was maintained at this value while in another treatment the concentration was raised to $15 \%$. There were five replications.

\section{RESULTS AND DISCUSSION}

No contamination was observed during the experiments. As shown in Fig. 2, the fruit expansion was strongly decreased after the increase in sucrose concentration. These experiments showed a depressive effect of a very high sucrose concentration on the fruit expansion. This could be explained on the basis of the lower water potential gradient between the fruit and the solution, while the sap viscosity was higher, according to previous models of the tomato fruit growth (Bussières, 1994, 1995). Although in these experiments with detached fruit, the fruit expansion was much lower than in vivo as generally observed in in vitro culture (Nitsch, 1951; Teitel et al., 1985), these experiments suggest that the fruit growth may be slowed down when the sap sucrose concentration, which may vary over the daytime, is very high. These experiments showed that the new device might be useful to make a number of studies to better understand the fruit growth.

\section{ACKNOWLEDGEMENTS}

The authors thank D. Grassely and M. Tisiot (Centre Technique Interprofessionnel des Fruits et Légumes, Balandran, France), who provided the fruits for this experiment.

\section{Literature Cited}

Bertin N. 2005. Analysis of the tomato fruit growth response to temperature and plant fruit load in relation to cell division, cell expansion and DNA endoreduplication. Ann. Bot. 95:439-447

Bussières P. 1994. Water import rate in tomato fruit: a resistance model. Ann. Bot. 73:7582

Bussières P. 1995. Dry matter and water import rates in the tomato fruit: a model incorporating the changes in sap viscosity and osmotic potential with temperature. Ann. Bot. 75:469-476

Nitsch J.P. 1951. Growth and development in vitro of excised ovaries. Am. J. Bot. 38:566-577

Teitel D.C., Arad S., Birnbaum E. and Mizrahi Y. 1985. Growth and developement of tomato fruits in vivo and in vitro. Plant Growth Regul. 3:179-189 


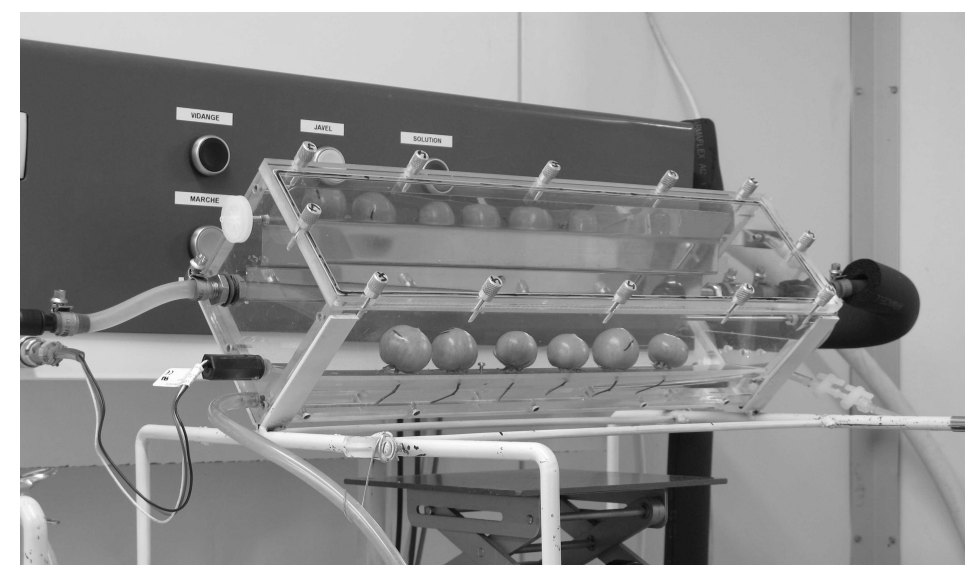

Fig. 1. Photo showing tomato fruit placed in a box of the device Casafruit. Six fruit are put on a support with holes to insert the pedicels. These are immersed in the sterile nutrient solution composed of Murashige and Skoog medium and of sucrose.

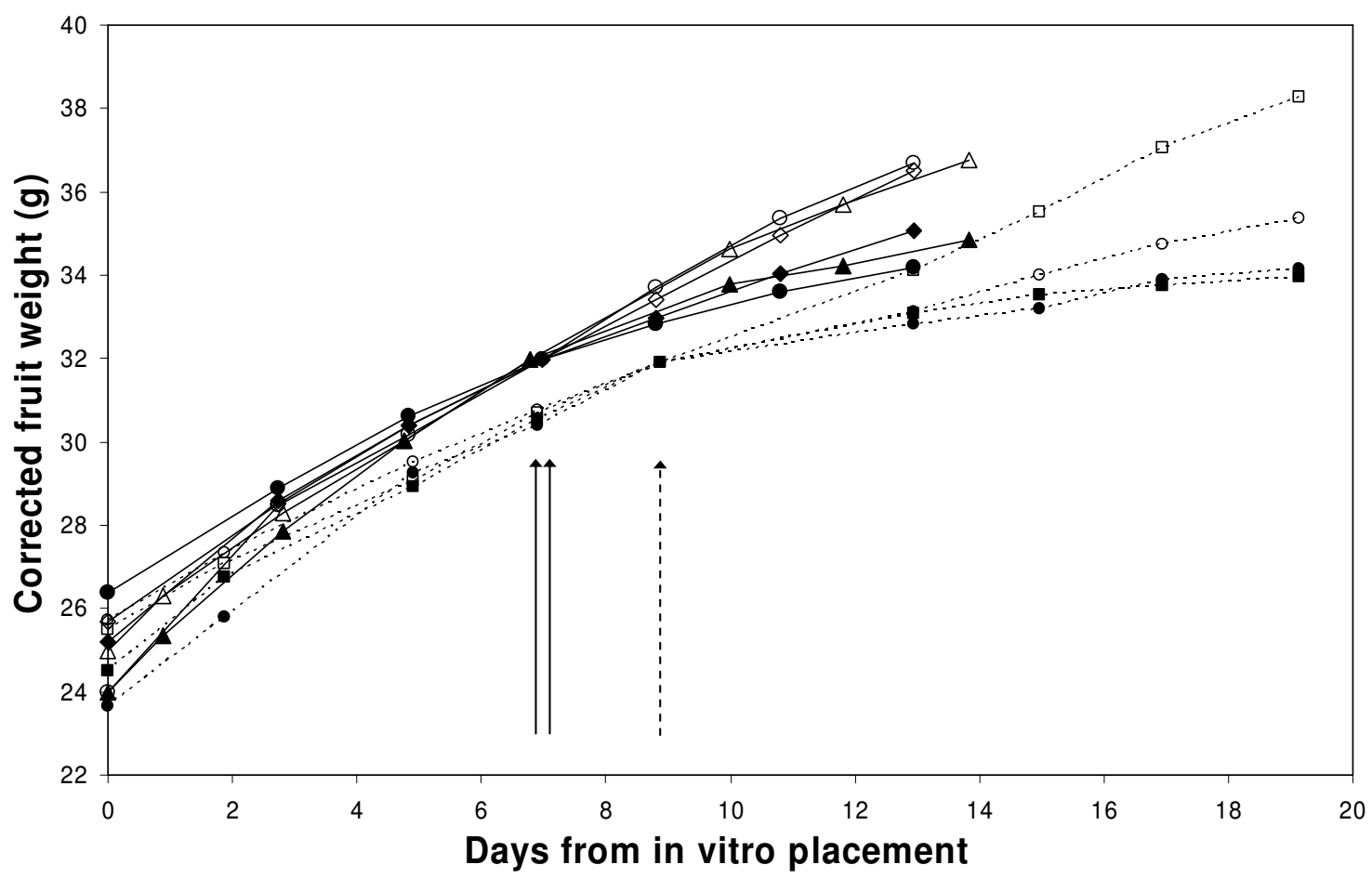

Fig. 2. Effect of increasing the sucrose concentration of the nutrient solution in the Casafruit device on mean detached tomato fruit weight (corrected to the mean fruit weight at the time of changing the sucrose concentration). The arrows indicate the moment where the sucrose concentration was increased in all five replications. The full arrows show this time for three trials with full curves; the dashed arrow shows this time for two trials with dotted curves. The empty symbols (squares for the three trials group) refer to the treatment where the concentration was equal to $5 \%$ throughout the period; the filled symbols (circles for the two trials group) refer to treatment where the concentration was increased from $5 \%$ to $15 \%$ on the indicated date. 